\title{
PROTEIN INTAKE AND LOSS OF PROTEOSTASIS IN THE ELDERY
}

\author{
A. N. KIRANA ${ }^{1}$, E. PRAFIANTINI ${ }^{1}$, N. S. HARDIANY $Y^{2,3 凶}$ \\ ${ }^{1}$ Department of Nutrition, Faculty of Medicine, Universitas Indonesia - \\ Dr. Cipto Mangunkusumo General Hospital, Jakarta, Indonesia; \\ ${ }^{2}$ Department of Biochemistry and Molecular Biology, \\ Faculty of Medicine, Universitas Indonesia; \\ ${ }^{3}$ Center of Hypoxia and Oxidative Stress Studies, \\ Faculty of Medicine, Universitas Indonesia;

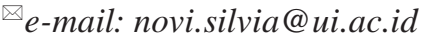

Received: 29 June 2020; Accepted: 17 December 2020

Ageing is a process of declining bodily function and a major risk factor of chronic diseases. The declining bodily function in ageing can cause loss of proteostasis (protein homeostasis), which is a balance between protein synthesis, folding, modification and degradation. For the elderly, adequate protein intake is necessary to prevent sarcopenia, frailty, fracture and osteoporosis as well as reduced resistance to infection. However, increasing the protein intake can enhance the risk of oxidized protein formation, loss of proteostasis and degenerative disorder occurrence. On the other hand, several studies show that protein restriction would increase longevity. The aim of this review was to explain the importance of determining the right amount and composition of protein intake for the elderly. Oxidative stress and molecular mechanism of proteostasis loss in ageing cells as well as its suppression pathway by protein restriction are discussed in this review.

Ke y w o rd s: ageing, proteostasis loss, dietary proteins, oxidative stress, mTOR.

$\mathrm{T}$ he global proportion of the elderly population (>60 years old) expected to increase continuously from 600 million in 2000 to more than 2 billion in 2050 [1]. Health varies between individuals as they age. Some generally have health conditions similar to people of a younger age, while others experience a deterioration of their physical and mental capacity. Cellular and tissue dysfunction in ageing process increase frailty and age-related disease [2-4].

Ageing itself can be defined as a degenerative process that decreases the fitness level and the body's ability to maintain homeostasis, increasing the possibility of death [5]. Many theories explain the molecular mechanism of ageing, however it falls into 2 categories that are programmed and damage or error theory. Programmed theory explains that ageing occurres according to biological time clock [6]. While the damage or error theory concern on environmental influence which stimulate accumulation of damage at several stages as the cause of ageing.
There are three major sources which responsible for accumulation of cellular damage, 1) excessive reactive oxygen species (ROS) as a cause of oxidative damage; 2) nutritional metabolites that interact with ROS, 3) error in molecular process such as DNA duplication, transcription, and translation [5, 8-10]. One of the sources of oxidative damage is oxidized protein measured by carbonyl level. The increase in carbonyl level can be found in patients with Alzheimer's, cancer, heart disease, diabetes mellitus, as well as among the elderly [11-15].

The current recommended protein intake for the elderly population is $0.8 \mathrm{~g} / \mathrm{kg} / \mathrm{day}$, which is apparently not adequate to maintain muscle mass. In old age, often there is a reduction of muscle mass or sarcopenia, which can increase morbidity and mortality. Dietary essential amino acids (EAAs) has an important role in stimulation of muscle protein synthesis. Combination of EAAs and nonessential amino acids (NEAAs) has same extent in muscle protein synthesis compared with EAAs only [16-18].

(C) 2021 Kirana A. N. et al. This is an open-access article distributed under the terms of the Creative Commons Attribution License, which permits unrestricted use, distribution, and reproduction in any medium, provided the original author and source are credited. 
Along with the ageing process, a disturbance in protein anabolism and an increase in protein degradation occur, along with a high requirement of protein intake [16, 19]. Increase in protein intake prevent muscle mass loss by increasing the availability of amino acids and activating mammalian target of rampamycin (mTOR) for muscle mass synthesis. The mTOR functiones as a regulator of growth and cell proliferation, which is closely related to the lifespan of cells and organisms [20].

On the other hand, high protein intake should be well-advised, considering that in older age there is a loss of homeostasis, which causes an increase in oxidized protein. Accumulated oxidized protein, which plays a role in degenerative diseases, cannot be repaired or degraded. This condition leads to formation of protein aggregates [2, 3, 5]. An animal study aimed to show that protein restriction would reduce tumor-related mTORC1 activities; the researchers hoped that protein restriction could be a choice in therapy not only for tumor but also for other degenerative diseases [21]. Understanding protein intake and loss of protein homeostasis in the elderly is necessary to determine the correct recommendation for protein intake. In the present minireview, we studied several articles from two databases (Pubmed \& Science Direct) published over the past three decades. The search terms from both databases were oxidative stress, protein intake, muscle mass, and proteostasis in ageing. A total of 23 studies were retrieved and 49 per-reviewed articles were found to be relevant to this review. Our objective here is to elaborate the importance of appropriate protein intake in elderly in which the disturbance of protein homeostasis occurred in ageing cells. In addition, oxidative stress in ageing, molecular mechanism of loss of proteostasis and its inhibition pathway through protein restriction are described in this review.

\section{Oxidative Stress in Ageing}

Harman first mentioned the ageing theory related to free radicals in 1956 [10, 22]. This theory postulated the ability of free radicals to cause ageing as a result of material damage accumulation. Reactive Oxygen Species (ROS) is the main cause of oxidative stress. Considering the importance of oxygen in maintaining human life, oxidative process and ROS formation were inseparable. ROS is formed not only from the bodily process but also from environmental exposure. The oxidative process can trigger an increase in macromolecular damage as in the Deoxyribonucleic acid (DNA), lipid, and protein $[3,5,23]$.

Mitochondria is an organelle that plays an important role in energy metabolism and other cellular processes such as fatty acid $\beta$-oxidation, maintaining calcium concentration in mitochondria matrix, metabolism of amino acid, and regulation of cell life span, including apoptosis, steroid synthesis, and hormonal signals. This organelle breaks down organic components into water and carbon dioxide to release energy in the form of adenosine triphosphate (ATP). Mitochondria is the main organelle that produces ROS formed in the electron transport chain. The electron released in this process bind with oxygen and produce free radicals in the short lifespan. Free radicals can change non-radical components into radical components causing oxidative damage [23-25]. Oxidative stress that causes molecular damage can induce both repair and degradation system. During ageing, those systems are less effective and cause accumulation of damage, leading to cellular defects, tissue dysfunction, and decreasing physiologic function [26]. The impact of oxidative stress to ageing process can be seen in Fig. 1.

Pandey et al. studied 80 healthy adults aged 18 to 85 years and found that an increase in age would reduce the plasma antioxidant capacity and increase the plasma protein carbonyl [15]. An increase in protein carbonyl has a significant correlation with a decrease in plasma antioxidant activity in ageing. The decreasing degradation system in the muscle during ageing is still controversial. It is caused by the use of different models or analysis of different muscle types. Type II fibers are more prone to atrophy during ageing than type I fibers $[11,27]$.

\section{Recommended Dietary Protein Intake for the Elderly}

The recommended dietary allowance (RDA) for protein by the Food and Nutrition Board of the United States National Academy of Science is 0.8 $\mathrm{g} / \mathrm{kg} /$ day for adults, regardless of age. The latest evidence showed that higher protein more than recommended would increase health, accelerate the disease healing process, and maintain functional state in older years. Higher protein demand among older adults is due to disorder in protein anabolic response, and extensive protein catabolism following inflammation, chronic disease, and nutrient deficiency. Therefore, appropriate protein intake is impor- 


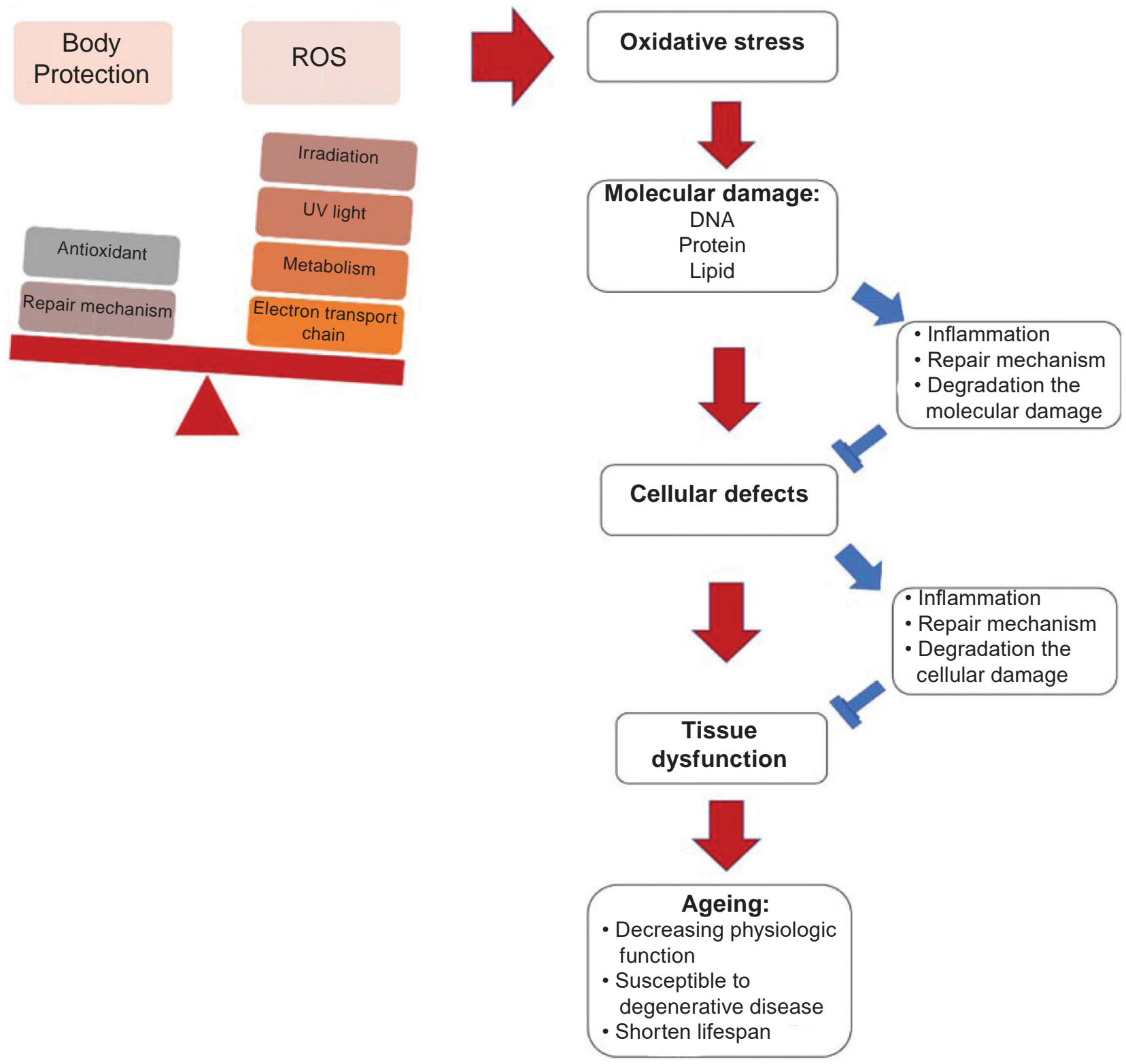

Fig. 1. Oxidative stress in the ageing process. An imbalance between free radical and body protection, including antioxidants, can cause oxidative stress and then molecular damage. The damage can accumulate and lead to cellular defects, tissue dysfunction, and decreasing physiologic function to maintain homeostasis. Abbreviations: ROS - reactive oxygen species; DNA - deoxyribose nucleic acid

tant to maintain good health in the elderly population [17-19].

Ageing is also related to the progressive deterioration of the resting metabolic rate by as much as $1-2 \%$ for each decade starting from 20 years old. This deterioration is closely related to the decrease in fat-free mass, which consists of tissues with an active metabolism. More than $50 \%$ of the total body weight of the young population is muscle mass, but this can decrease by up to $25 \%$ at $75-80$ years old.
Loss of muscle mass is followed by an increase in fat mass without an increase in body weight. The biggest loss, up to $40 \%$, occurs at the lower extremity muscles [28-31]. Declines in muscle mass and function during ageing increase the prevalence of both sarcopenia and frailty. This condition lead to morbidity and mortality [32, 33].

In order to inhibit sarcopenia and frailty, the right amount and composition of protein intake such as EAAs composition for elderly must be well con- 
sidered. EAAs especially leucine are robust stimulators for muscle protein synthesis. The stimulation related to the protein kinase mTORC1 [34]. A controlled clinical trial shows increasing the proportion of leucine in EAAs can be overcome response of muscle protein synthesis following ingestion of low doses of amino acid. The data indicate a potential beneficial effect of leucine in formulation of any amino acid or supplement [35]. Moreover, the type of protein intake such as whey and casein protein for elderly should be evaluated. Elderly adults showed an increment in body protein after consuming whey protein compared to younger adults. In younger men, casein protein stimulated a bigger increase in protein compared to whey protein. In older subjects, the protein quickly rises after whey protein intake and slowly rise after casein intake [36, 37]. Therefore, whey protein can be more beneficial in preventing protein loss in older age. However, we still need more studies to understand the mechanism of protein loss in the ageing process. Other studies show an increase in muscle strength in elderly adults after $20 \mathrm{~g}$ /day supplementation of whey protein combined with resistance training compared to casein supplementation [38]. Aside from the difference in the metabolism rate of protein in older adults, there is also a decrease in chewing ability. For example, minced meat is easier to digest than whole meat and is thus more effective in increasing body amino acid. The texture of protein food source must be considered [28, 39].

In older age, there is a disturbance in protein anabolism response (anabolic resistance). Therefore, the combination of protein intake with physical training can be effective to maintain muscle mass. The long-term effect of physical training increase insulin sensitivity, which also plays a role in protein synthesis regulation. Besides, the supplementation of branched-chain amino acid, especially leucine, can increase protein anabolism response. Protein supplementation gains muscle mass and strength during prolonged resistance exercise in younger and older people [19, 40, 41].

A study by Campbell et al. showed that healthy elderly people would have a negative nitrogen balance after consuming protein according to the dietary requirement for 10 days [42]. A longitudinal study of men and women aged 55 to 77 years showed that a protein intake of $0.8 \mathrm{~g} / \mathrm{kg} /$ day for three months would cause physiological adaptation in the reduction of muscle mass while the body's leucine metabolism would be maintained in good physiologi- cal condition [43]. Many studies highlighted that the current recommendation for protein intake $0.8 \mathrm{~g} / \mathrm{kg} /$ day is not sufficient to fulfill an individual's physiological need and metabolism in older age. Low protein intake for a long period can force the body to adapt by breaking down muscle mass to maintain nitrogen balance, causing sarcopenia, vulnerability, and deterioration of quality of life. The European Society for Clinical Nutrition and Metabolism (ESPEN) recommend for healthy older people, at least, $1.0-1.2 \mathrm{~g} / \mathrm{kg} /$ day proteins with EAAs components and daily activity or exercise training [28, 44, 45].

\section{Loss of Proteostasis in the Elderly}

Proteostasis is achieved by good coordination of many actions, including protein synthesis, folding, and degradations. The Proteostasis process involves the autophagy machinery, molecular chaperones, and ubiquitin-proteasome system (UPS) [46]. Maintaining proteostasis requires control not only in the folding process but also in the conformational, localization, and degradation. Production of misfolded protein increase by stochastic errors in protein synthesis at the level of transcription, mRNA maturation, translation, and post-translational modification. Surveillance system inside cells detect the damage protein then repair or eliminate from the cells. Poor surveillance can promote damage protein. Misfolded protein, abnormal cleavage or undesirable post-translational modification cause self-assembling into toxic structure or aggregation into cytosolic inclusion [46-49].

Misfolded and aggregated proteins must be removed from the system by the protein degradation process. Increasing aggregated and damage protein formation is exacerbated in aging, disease-associated mutation, and environmental stress [47]. Protein can be degraded either individually or in groups by proteasome or lysosomes. Proteasomes are large complexes that consist of a 195 regulatory cap and a $20 \mathrm{~S}$ proteolytic core. The regulatory part recognizes the substrate that binds to ubiquitin chains. Regulatory particles remove ubiquitin chains and rapidly degrade into peptides in the $20 \mathrm{~S}$ core. The process initiated by addition of polyubiquitin chains with stepwise activity of E1 activating enzymes, E2 conjugating enzymes, E3 ubiquitin ligases. This system cannot degrade unfolded or large protein complexes. Alternatively, the large substrate can be directed to the lysosome as the terminal steps of autophagy $[46,50]$. Autophagy complements work in three mechanism, they are macroautophagy, chape- 
rone-mediated autophagy, and microautophagy. Autophagy is controlled by mTOR complex 1 (mTORC1) and mTOR complex 2 (mTORC2), connect to proteostasis network based on nutritional status of organism, cellular metabolic rate, and protein synthesis rate [50, 51].

The ability to maintain homeostasis is critical for survival. Loss of proteostasis plays an important role in the ageing process at the cellular level through the accumulation of protein aggregates, misfolded protein, oxidative damage, post-translational modification, and change in the rate of protein turnover. The protein refolding process is mediated by the chaperone, and the protein degradation system is run by lysosome and proteasome [26]. Molecular chaperones or heat shock proteins are stress factor induced in response to elevated temperature and other stress condition. Chaperone participated in control of quality for proteins located in cytosol or in intracellular compartments [49, 52].

The molecular chaperone increases during stress as a feedback from the transcription of heat shock factor-1 (HSF-1) and molecular chaperone Hsp90. Normally, HSF-1 is inactive and bound to Hsp90. But during stress, there is an increase in misfolded proteins, which also bind to Hsp90, thereby detaching the previous bind with HSF-1 and resulting in the activation of HSF-1. This process adds molecular chaperones assisting the refolding of denatured protein. The chaperone system can maintain homeostasis during mild stress or transition. But during chronic stress, the balance between chaperones and misfolded protein cannot be maintained, causing the damaged protein to gather and form aggregates. The effect of increased damaged protein, protein aggregation, and a decrease in the protein degradation process plays a role in reducing protein homeostasis along with age [2, 53, 54].

Age can decrease the function of the proteasome system. Previous studies stated that, along with age, there is an increase in post-translational oxidized protein and a reduction in peptidase activity $[55,56]$. Disturbance in the lysosomal system related to ageing is described by Brunk and Terman [24]. During the ageing process, there is a dysfunction in lysosome $\mathrm{pH}$ regulation and a reduction in lysosome stability. This condition reduces the lysosome's ability to degrade the oxidized protein and defend against free radical formation [57]. Moreover, a change in protein expression pattern occurred in ageing process [58]. Tanaka et al conducted proteomic profiling on 240 healthy people ages between 22-93 years in order to elaborate aging biomarkers. There were 197 proteins positively associated with age in which the strongest one was Growth differentiation factor 15 (GDF15) [58]. Secretion of GDF15 act as a marker for mitochondrial dysfunction and its expression is induced by oxidative stress in aging process. (59) In order to maintain normal function of mitochondria, well proteostasis system is required. Accumulation of unfolded and misfolded protein in mitochondria stimulate GDF15 expression to control energy homeostasis [60].

Evidence showed that the ageing process would increase the level of oxidized protein in the brain. The protein is vulnerable to oxidative disorder causing conformation or covalent damage. Almost all covalent damage is irreversible and so must be degraded to prevent accumulation and cross-linking. Different from conformational damage, which can be repaired by molecular chaperone binding to the hydrophobic surface and assisting in refolding, the chaperone system becomes ineffective when there is increased damage as seen in the ageing process $[2,52,61]$.

Loss of proteostasis, which occurs in the ageing process, can be suppressed by calorie restriction, reduction of insulin-like growth factor-1 (IGF-1) signal, and administration of rapamycin. Calorie restriction and administration of rapamycin inhibit mTOR work target, which is protein translation, and provide an opportunity for the cell to carry out a repair mechanism and degrade damaged protein. Calorie restriction also induces the upregulation of several heat shock proteins that have a crucial role in quality control in proteostasis. Starvation in NEEAs reported extent replication lifespan in yeast. Meanwhile, an increase in protein intake increase mTOR activity, which plays a role in the ageing process $[62,63]$.

\section{The mTOR Inhibition by Protein \\ Restriction to Increase Lifespan}

The activity of mTOR is correlated with the regulation of cell growth, proliferation, apoptosis, and inflammation. Therefore, the mTOR activity affect the ageing process and lifespan of the organism. The mTOR protein kinase is found in 2 complexes, mTORC1 and mTORC2. Each has a different substrate. The mTOR signal pathway is the controller of growth regulation and cell proliferation. Activation of mTORC1 takes place in cellular organelles, such as peroxisome or lysosome. Activation of mTORC1 
needs energy sources, such as glucose, amino acid, lipids, oxygen, and a high ratio of ATP to AMP. Besides that, a high concentration of amino acid, especially arginine and leucine, stimulate mTORC1 activation. In humans, protein or amino acid concentration produce activation of mTOR and insulin secretion which increase blood pressure. The mTOR activation also affect cognitive, tissue physiology, stem cell, and other bodily functions. The mTOR activation by high protein intake, in the long run, decrease the state of health by increasing the risk of some conditions, such as neurodegenerative diseases including Alzheimer and Parkinson [21, 64, 65].

Calorie restriction achieves mTOR inhibition through decreased Phosphoinositol-3-kinase (PI3K) activity and increased AMP-activated Protein Kinase (AMPK) activity. The ageing process, cancer, and energy sources (glucose, amino acids, lipid) activate PI3K and increase mTORC1 activity. In other hand, calorie and protein restriction activate AMPK which leads to autophagy in the protein degradation process. Degradation of protein, including misfolded protein, prevent the formation of protein aggregates and prolong lifespan [66, 67]. The process is illustrated in Fig. 2.

Many studies about amino acids restriction show the protein restriction inhibit mTOR and increase lifespan. This is because mTORC1 inhibition reduce the mRNA translation, giving the body an opportunity to conduct protein degradation or repair itself to maintain homeostasis and prevent the accumulation of damaged protein and protein aggregation, both important in combating many degenerative diseases [66, 68-70]. In 2017, Kolodziej et al. studied the effect of long-term high protein intake on the saliva gland of test animals and found that longterm protein intake can increase oxidative damage markers and total oxidant state [71]. Ayala et al. in

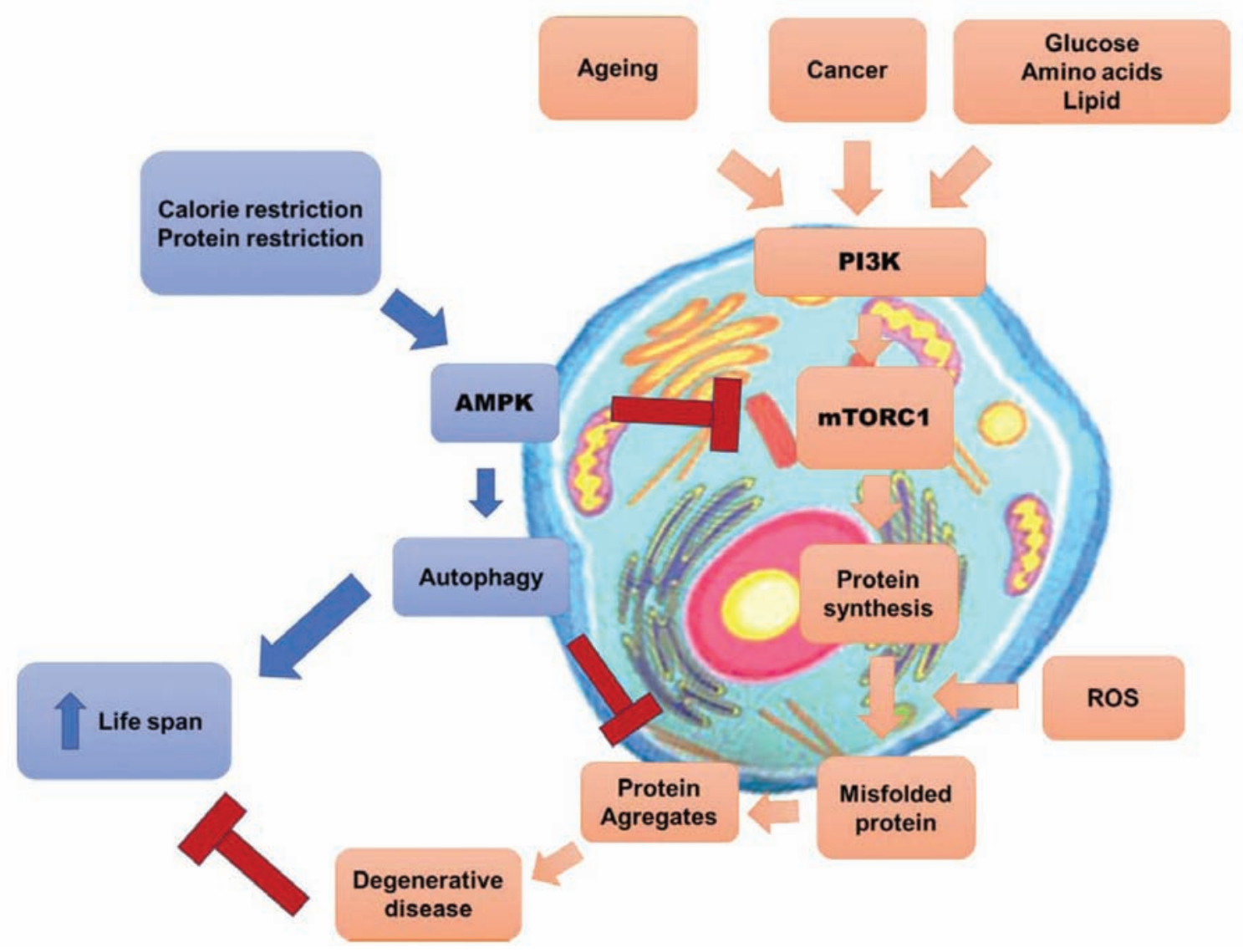

Fig. 2. mTORC1 inhibition to increase lifespan. Calorie and protein restrictions decrease mTOR activity through the activation AMPK that increases the autophagy process. Autophagy prevent the accumulation of misfolded protein and formation of protein aggregates. This condition decreased the risk of degenerative diseases and prolong lifespan. Abbreviations: PI3K - Phosphoinositol-3-Kinase; AMPK - AMP-activated protein kinase; mTORC1 - Mammalian target of rapamycin complex 1; ROS - reactive oxygen species 
2007 found that calorie and protein restrictions can reduce ROS production in mitochondria and reduce oxidative damage in DNA, protein, and lipid in mice liver tissue [72]. The mTOR activity inhibition itself does not delay the ageing process but is more inclined towards preventing age-related chronic diseases [21].

Conclusion. Ageing affected functional status of older adults by promoting catabolism and thus adequate intake of protein is essential for maintaining muscle mass and preventing sarcopenia. Regarding that, the body increases the need for protein intake in older age, at least $1.0-1.2 \mathrm{~g} / \mathrm{kg} /$ day. But in the ageing process, there is also loss of proteostasis, causing the accumulation of misfolded, damaged, and aggregated protein, which is a dominant factor in many degenerative diseases. Studies on test animals demonstrated that protein restriction is beneficial for reducing mTOR activity and mRNA translation to provide an opportunity for cells to carry out repair mechanisms and degradation of the damaged protein. The recommendation for protein intake must be determined correctly to be able to prevent sarcopenia. Moreover, an appropriate of protein intake should be considered in order to prevent oxidative damage in degenerative diseases due to loss of proteostasis. Therefore, a long-term cohort study on humans is needed to evaluate the effect variation of protein intake toward oxidative stress.

Conflict of interest. Authors have completed the Unified Conflicts of Interest form at http://ukrbiochemjournal.org/wp-content/uploads/2018/12/ coi_disclosure.pdf and declare no conflict of interest.

Funding. The grant of International Indexed Publication for Final Assignment of the Postgraduate Student (Hibah PITTA A) 2019 from the Universitas Indonesia.

\section{СПОЖИВАННЯ ПРОТЕЇНІВ ТА ВТРАТА ПРОТЕОСТАЗУ ПІД ЧАС СТАРІННЯ}

\author{
A. N. Kirana ${ }^{1}$, E. Prafiantini ${ }^{1}$, \\ N. S. Hardiany ${ }^{2,3 凶}$
}

${ }^{1}$ Department of Nutrition, Faculty of Medicine, Universitas Indonesia - Dr. Cipto Mangunkusumo General Hospital, Jakarta, Indonesia;

${ }^{2}$ Department of Biochemistry and Molecular Biology, Faculty of Medicine, Universitas Indonesia;

${ }^{3}$ Center of Hypoxia and Oxidative Stress Studies, Faculty of Medicine, Universitas Indonesia;

凶e-mail: novi.silvia@ui.ac.id

Старіння - це процес зниження функцій організму та головний фактор ризику хронічних захворювань. Зниження функцій організму за старіння може спричинити втрату протеостазу (протеїнового гомеостазу), тобто здатності підтримувати баланс між синтезом, згортанням, модифікацією та деградацією протеїнів. Людям похилого віку необхідне достатнє споживання протеїнів для запобігання саркопенії, слабкості, переломів, остеопорозу, а також зниженої стійкості до інфекції. Однак збільшене споживання протеїнів може посилити ризик утворення окисленого протеїну, втрати протеостазу та виникнення дегенеративних розладів. 3 іншого боку, є дані про те, що обмежене споживання протеїнів може подовжити тривалість життя. Метою цього огляду було пояснити важливість визначення кількості та складу протеїнів для споживання людьми похилого віку. Обговорено розвиток оксидативного стресу в клітинах, що старіють, молекулярні механізми втрати протеостазу та шляхи його запобігання через обмеження споживання протеїнів.

К л ю чо в і с лов а: старіння, протеостаз, протеїнова дієта, оксидативний стрес, mTOR. 


\section{References}

1. United Nations, Department of Economic and Social Affairs. World populations prospects: The 2017 revision, Ky Findings, an Advance Tables. New York: United Nations. ESA/P/WP/248.P.1-10.

2. Mc Auley MT, Guimera AM, Hodgson D, Mcdonald N, Mooney KM, Morgan AE, Proctor CJ. Modelling the molecular mechanisms of aging. Biosci Rep. 2017; 37(1): BSR20160177.

3. Kirkwood TBL. Understanding the odd science of aging. Cell. 2005; 120(4): 437-447.

4. Kirkwood TBL, Boys RJ, Gillespie CS, Proctor CJ, Shanley DP, Wilkinson DJ. Towards an e-biology of ageing: integrating theory and data. Nat Rev Mol Cell Biol. 2003; 4(3): 243-249.

5. Rattan SIS. Theories of biological aging: genes, proteins, and free radicals. Free Radic Res. 2006; 40(12): 1230-1238.

6. Sergiev PV, Dontsova OA, Berezkin GV. Theories of aging: an ever-evolving field. Acta Naturae. 2015; 7(1): 9-18.

7. Jin K. Modern Biological Theories of Aging. Aging Dis. 2010;1(2):72-74.

8. Grune T, Jung T, Merker K, Davies KJA. Decreased proteolysis caused by protein aggregates, inclusion bodies, plaques, lipofuscin, ceroid, and 'aggresomes' during oxidative stress, aging, and disease. Int $J$ Biochem Cell Biol. 2004; 36(12): 2519-2530.

9. Suji G, Sivakami S. Glucose, glycation and aging. Biogerontology. 2004; 5(6): 365-373.

10. Harman D. The free radical theory of aging. Antioxid Redox Signal. 2003; 5(5): 557-561.

11. Wang Z, Wang Y, Liu H, Che Y, Xu Y, Lingling E. Age-related variations of protein carbonyls in human saliva and plasma: is saliva protein carbonyls an alternative biomarker of aging? Age (Dordr). 2015; 37(3): 9781.

12. Gubandru M, Margina D, Tsitsimpikou C, Goutzourelas N, Tsarouhas K, Ilie M, Tsatsakis AM, Kouretas D. Alzheimer's disease treated patients showed different patterns for oxidative stress and inflammation markers. Food Chem Toxicol. 2013; 61: 209-214.

13. Mannello F, Ligi D, Canale M. Aluminium, carbonyls and cytokines in human nipple aspirate fluids: Possible relationship between inflammation, oxidative stress and breast cancer microenvironment. J Inorg Biochem. 2013; 128: 250-256.

14. Sefi M, Fetoui H, Makni M, Zeghal N. Mitigating effects of antioxidant properties of Artemisia campestris leaf extract on hyperlipidemia, advanced glycation end products and oxidative stress in alloxan-induced diabetic rats. Food Chem Toxicol. 2010; 48(7): 1986-1993.
15. Pandey KB, Mehdi MM, Maurya PK, Rizvi SI. Plasma protein oxidation and its correlation with antioxidant potential during human aging. Dis Markers. 2010; 29(1): 1-36.

16. Baum JI, Kim IY, Wolfe RR. Protein Consumption and the Elderly: What Is the Optimal Level of Intake? Nutrients. 2016; 8(6): 359.

17. Wolfe RR. The role of dietary protein in optimizing muscle mass, function and health outcomes in older individuals. Br J Nutr. 2012; 108(Suppl 2): S88-S93.

18. Morais JA, Chevalier S, Gougeon R. Protein turnover and requirements in the healthy and frail elderly. $J$ Nutr Health Aging. 2006; 10(4): 272-283.

19. Bauer J, Biolo G, Cederholm T, Cesari M, CruzJentoft AJ, Morley JE, Phillips S, Sieber C, Stehle P, Teta D, Visvanathan R, Volpi E, Boirie Y. Evidencebased recommendations for optimal dietary protein intake in older people: a position paper from the PROT-AGE Study Group. J Am Med Dir Assoc. 2013; 14(8): 542-559.

20. Baum JI, Wolfe RR. The Link between Dietary Protein Intake, Skeletal Muscle Function and Health in Older Adults. Healthcare (Basel). 2015; 3(3): 529543.

21. Lamming DW, Cummings NE, Rastelli AL, Gao F, Cava E, Bertozzi B, Spelta F, Pili R, Fontana L. Restriction of dietary protein decreases mTORC1 in tumors and somatic tissues of a tumor-bearing mouse xenograft model. Oncotarget. 2015; 6(31): 31233-31240.

22. Cui H, Kong Y, Zhang H. Oxidative stress, mitochondrial dysfunction, and aging. J Signal Transduct. 2012; 2012: 646354.

23. Kudryavtseva AV, Krasnov GS, Dmitriev AA, Alekseev BY, Kardymon OL, Sadritdinova AF, Fedorova MS, Pokrovsky AV, Melnikova NV, Kaprin AD, Moskalev AA, Snezhkina AV. Mitochondrial dysfunction and oxidative stress in aging and cancer. Oncotarget. 2016; 7(29): 4487944905.

24. Brunk UT, Terman A. The mitochondriallysosomal axis theory of aging: accumulation of damaged mitochondria as a result of imperfect autophagocytosis. Eur J Biochem. 2002; 269(8): 1996-2002.

25. Ray PD, Huang BW, Tsuji Y. Reactive oxygen species (ROS) homeostasis and redox regulation in cellular signaling. Cell Signal. 2012; 24(5): 981-990.

26. Reeg S, Grune T. Protein Oxidation in Aging: Does It Play a Role in Aging Progression? Antioxid Redox Signal. 2015; 23(3): 239-255.

27. Fernando R, Drescher C, Nowotny K, Grune T, Castro JP. Impaired proteostasis during skeletal muscle aging. Free Radic Biol Med. 2019; 132: 5866. 
28. Nowson C, O'Connell S. Protein Requirements and Recommendations for Older People: A Review. Nutrients. 2015; 7(8): 6874-6899.

29. Hughes VA, Frontera WR, Roubenoff R, Evans WJ, Singh MA. Longitudinal changes in body composition in older men and women: role of body weight change and physical activity. Am J Clin Nutr. 2002; 76(2): 473-481.

30. Montero-Fernández N, Serra-Rexach JA. Role of exercise on sarcopenia in the elderly. Eur $J$ Phys Rehabil Med. 2013; 49(1): 131-143.

31. Short KR, Nair KS. The effect of age on protein metabolism. Curr Opin Clin Nutr Metab Care. 2000; 3(1): 39-44.

32. Strandberg TE, Pitkälä KH. Frailty in elderly people. Lancet. 2007; 369(9570): 1328-1329.

33. Ozaki A, Uchiyama M, Tagaya H, Ohida T, Ogihara R. The Japanese Centenarian Study: autonomy was associated with health practices as well as physical status. J Am Geriatr Soc. 2007; 55(1): 95-101.

34. Anthony JC, Yoshizaw F, Anthon TG, Vary TC, Jefferson LS, Kimball SR. Leucine stimulates translation initiation in skeletal muscle of postabsorptive rats via a rapamycin-sensitive pathway. J Nutr. 2000; 130(10): 2413-2419.

35. Katsanos CS, Kobayashi H, Sheffield-Moore M, Aarsland A, Wolfe RR. A high proportion of leucine is required for optimal stimulation of the rate of muscle protein synthesis by essential amino acids in the elderly. Am J Physiol Endocrinol Metab. 2006; 291(2): E381-E387.

36. Dangin M, Boirie Y, Guillet C, Beaufrère B. Influence of the protein digestion rate on protein turnover in young and elderly subjects. J Nutr. 2002; 132(10): 3228S-3233S.

37. Dangin M, Guillet C, Garcia-Rodenas C, Gachon P, Bouteloup-Demange C, Reiffers-Magnani K, Fauquant $\mathrm{J}$, Ballèvre $\mathrm{O}$, Beaufrère $\mathrm{B}$. The rate of protein digestion affects protein gain differently during aging in humans. J Physiol. 2003; 549(Pt 2): 635-644.

38. Karelis AD, Messier V, Suppère C, Briand P, RabasaLhoret R. Effect of cysteine-rich whey protein (immunocal ${ }^{\circledR}$ ) supplementation in combination with resistance training on muscle strength and lean body mass in non-frail elderly subjects: a randomized, double-blind controlled study. J Nutr Health Aging. 2015; 19(5): 531-536.

39. Grassi M, Petraccia L, Mennuni G, Fontana M, Scarno A, Sabetta S, Fraioli A. Changes, functional disorders, and diseases in the gastrointestinal tract of elderly. Nutr Hosp. 2011; 26(4): 659-668.

40. Wall BT, Hamer HM, de Lange A, Kiskini A, Groen BB, Senden JM, Gijsen AP, Verdijk LB, van Loon LJ. Leucine co-ingestion improves postprandial muscle protein accretion in elderly men. Clin Nutr. 2013; 32(3): 412-419.
41. Cermak NM, Res PT, de Groot LC, Saris WH, van Loon LJ. Protein supplementation augments the adaptive response of skeletal muscle to resistancetype exercise training: a meta-analysis. Am J Clin Nutr. 2012; 96(6): 1454-1464.

42. Campbell WW, Crim MC, Dallal GE, Young VR, Evans WJ. Increased protein requirements in elderly people: new data and retrospective reassessments. Am J Clin Nutr. 1994; 60(4): 501-509.

43. Campbell WW, Trappe TA, Wolfe RR, Evans WJ. The recommended dietary allowance for protein may not be adequate for older people to maintain skeletal muscle. J Gerontol A Biol Sci Med Sci. 2001; 56(6): M373-M380.

44. Courtney-Martin G, Ball RO, Pencharz PB, Elango R. Protein Requirements during Aging. Nutrients. 2016; 8(8): 492.

45. Deutz NEP, Bauer JM, Barazzoni R, Biolo G, Boirie Y, Bosy-Westphal A, Cederholm T, Cruz-Jentoft A, Krznariç Z, Nair KS, Singer P, Teta D, Tipton K, Calder PC. Protein intake and exercise for optimal muscle function with aging: recommendations from the ESPEN Expert Group. Clin Nutr. 2014; 33(6): 929-936.

46. Labbadia J, Morimoto RI. The biology of proteostasis in aging and disease. Annu Rev Biochem. 2015; 84: 435-464.

47. Klaips CL, Jayaraj GG, Hartl FU. Pathways of cellular proteostasis in aging and disease. J Cell Biol. 2018; 217(1): 51-63.

48. Santra M, Dill KA, de Graff AMR. Proteostasis collapse is a driver of cell aging and death. Proc Natl Acad Sci USA. 2019; 116(44): 22173-22178.

49. Koga H, Kaushik S, Cuervo AM. Protein homeostasis and aging: The importance of exquisite quality control. Ageing Res Rev. 2011; 10(2): 205-215.

50. Yang Z, Klionsky DJ. Mammalian autophagy: core molecular machinery and signaling regulation. Curr Opin Cell Biol. 2010; 22(2): 124-131.

51. Finley D. Recognition and processing of ubiquitinprotein conjugates by the proteasome. Annu Rev Biochem. 2009; 78: 477-513.

52. Bukau B, Weissman J, Horwich A. Molecular chaperones and protein quality control. Cell. 2006; 125(3): 443-451.

53. Proctor CJ, Soti C, Boys RJ, Gillespi CS, Shanley DP, Wilkinso DJ, Kirkwood TB. Modelling the actions of chaperones and their role in ageing. Mech Ageing Dev. 2005; 126(1): 119-131.

54. Proctor CJ , Lorimer IA. Modelling the role of the Hsp70/Hsp90 system in the maintenance of protein homeostasis. PLoS One. 2011; 6(7): e22038.

55. Friguet B, Bulteau AL, Chondrogianni N, Conconi M, Petropoulos I. Protein degradation by the proteasome and its implications in aging. Ann NY Acad Sci. 2000; 908: 143-154. 
56. Bulteau AL, Petropoulos I, Friguet B. Age-related alterations of proteasome structure and function in aging epidermis. Exp Gerontol. 2000; 35(6-7): 76777.

57. Terman A, Brunk UT. Oxidative stress, accumulation of biological 'garbage', and aging. Antioxid Redox Signal. 2006; 8(1-2): 197-204.

58. Tanaka T, Biancotto A, Moaddel R, Moore AZ, Gonzalez-Freire M, Aon MA, Candia J, Zhang P, Cheung F, Fantoni G, CHI consortium, Semba RD, Luigi Ferrucci L. Plasma proteomic signature of age in healthy humans. Aging Cell. 2018; 17(5): e12799.

59. Fujita Y, Taniguchi Y, Shinkai S, Tanaka M, Ito M. Secreted growth differentiation factor 15 as a potential biomarker for mitochondrial dysfunctions in aging and age-related disorders. Geriatr Gerontol Int. 2016; 16(Suppl 1): 17-29.

60. Chung HK, Ryu D, Kim KS, Chang JY, Kim YK, Yi HS, Kang SG, Choi MJ, Lee SE, Jung SB, Ryu MJ, Kim SJ, Kweon GR, Kim H, Hwang JH, Lee CH, Lee SJ, Wall CE, Downes M, Evans RM, Auwerx J, Shong M. Growth differentiation factor 15 is a myomitokine governing systemic energy homeostasis. J Cell Biol. 2017; 216(1): 149-165.

61. Smith CD, Carney JM, Starke-Reed PE, Oliver CN, Stadtman ER, Floyd RA, Markesbery WR. Excess brain protein oxidation and enzyme dysfunction in normal aging and in Alzheimer disease. Proc Natl Acad Sci USA. 1991; 88(23): 10540-10543.

62. Basisty N, Meyer JG, Schilling B. Protein Turnover in Aging and Longevity. Proteomics. 2018; 18(5-6): e1700108.

63. Yang L, Licastro D, Cava E, Veronese N, Spelta F, Rizza W, Bertozzi B, Villareal DT, Hotamisligil GS, Holloszy JO, Fontana L. Long-Term Calorie Restriction Enhances Cellular Quality-Control Processes in Human Skeletal Muscle. Cell Rep. 2016; 14(3): 422-428.
64. Weichhart T. mTOR as Regulator of Lifespan, Aging, and Cellular Senescence: A Mini-Review. Gerontology. 2018; 64(2): 127-134.

65. Soultoukis GA, Partridge L. Dietary Protein, Metabolism, and Aging. Annu Rev Biochem. 2016; 85: 5-34.

66. Arbor S. Where and how in the mTOR pathway inhibitors fight ageing: Rapamycin, resveratrol, and metformin. from: Resveratrol - adding life to years, not adding years to life. Intech Open. 2019: 93-101.

67. Xie QB, Liang Y, Yang M, Yang Y, Cen XM, Yin G. DEPTOR-mTOR Signaling Is Critical for Lipid Metabolism and Inflammation Homeostasis of Lymphocytes in Human PBMC Culture. J Immunol Res. 2017; 2017: 5252840.

68. Fontana L, Partridge L. Promoting health and longevity through diet: from model organisms to humans. Cell. 2015; 161(1): 106-118.

69. Edwards C, Canfield J, Copes N, Brito A, Rehan M, Lipps D, Brunquell J, Westerheide SD, Bradshaw PC. Mechanisms of amino acid-mediated lifespan extension in Caenorhabditis elegans. BMC Genet. 2015; 16(1): 8.

70. Santos J, Leão C, Sousa MJ. Growth culture conditions and nutrient signaling modulating yeast chronological longevity. Oxid Med Cell Longev. 2012; 2012: 680304.

71. Kołodziej U, Maciejczyk M, Niklińska W, Waszkiel D, Żendzian-Piotrowska M, Żukowski P, Zalewska A. Chronic high-protein diet induces oxidative stress and alters the salivary gland function in rats. Arch Oral Biol. 2017; 84: 6-12.

72. Ayala V, Naudí A, Sanz A, Caro P, Portero-Otin M, Barja G, Pamplona R. Dietary protein restriction decreases oxidative protein damage, peroxidizability index, and mitochondrial complex I content in rat liver. J Gerontol A Biol Sci Med Sci. 2007; 62(4): 352-360. 